\title{
COMPARATIVE STUDIES BETWEEN PEFLOXACIN AND TIAMULIN AGAINST MYCOPLASMA IN TURKEY
}

\author{
HALLA M. KALILL ${ }^{1}$; NESEREEN SHAWKY ${ }^{1}$; HALLA A. EL SAID ${ }^{1}$ AND \\ HAMADA, M. HASHEM ${ }^{2}$ \\ ${ }^{1}$ Biochemistry, Animal Health Research Institute (Zagazig Branch) Agriculture \\ Research Center \\ ${ }^{2}$ Bacteriology, Animal Health Research Institute (Zagazig Branch) Agriculture \\ ResearchCenter
}

Received: 10 October 2021; Accepted: 17 November 2021

\begin{abstract}
Samples form lungs, trachea and air sacs were collected from 40 turkey poults suffering from respiratory signs for bacteriological examination for isolation and identification mycoplasma spp. The results revealed, 18 (45\%) samples were positive (+ve) for mycoplasma spp. Antibiogram study of isolates revealed that pefloxacin and tiamulin was effective against mycoplasma. A total of 40, one-day old poults provide free from mycoplasma infection were divided in to 4 equal groups. $1^{\text {st }}$ group healthy negative (-ve control) $2^{\text {nd }}, 3^{\text {rd }} \& 4^{\text {th }}$ groups were artificially infected with Mycoplasma gallisepticum $(M G), 2^{\text {nd }}$ group infected non treated (+ve control), $3^{\text {rd }}$ group infected treated with $5 \mathrm{mg}$ pefloxacin $/ \mathrm{kg}$ bwt in drinking water for 5 successive days and $4^{\text {th }}$ groups was infected treated with $25 \mathrm{mg}$ tiamulin/kg bwt in drinking water for 5 successive days, At $1^{\text {st }}$ and $10^{\text {th }}$ days post treatment 5 poults from each group were sacrificed for record lesion scores $\%$ and two blood samples were taken from each poults for hematobiochemical parameters study. Poults infected with Mycoplasma gallisepticum revealed los s of appetite, depression, sneezing, conjunctivitis, frothy exudation in eyes, air sacculitis $7(70 \%)$, pericarditis $7(70 \%)$, perihepatitis $8(80 \%)$ \& mortality rate $4(40 \%)$ beside induces significant increase in WBCs, AST ALT, ALP uric acid, creatinine and significant decrease in weight gain. Phagocytic \%, index, killing \% IgA, IgG, IgM, T protein, albumin and globulin. Medication mycoplasma gallisepticum by tiamulin or pefloxacin revealed disappears of clinical signs, reduced mortality rate to $10 \%$, mild lesion scores re-isolation rate of Mycoplasma gallisepticum from poults treated with pefloxacin was (20\%) and (10\%) for tiamulin beside improve in hematobiochemical parameters and returned to nearly normal level at $10^{\text {th }}$ day post treatment. It could be concluded that pefloxacin and tiamulin was effective in treatment Mycoplasma gallisepticum in poults and ameliorate severity of its lesion s besides improving adverse effect in hematobiochemical parameters.
\end{abstract}

Keyword: Mycoplasma gallisepticum; pefloxacin; tiamulin; turkey; hematobiochemical.

\section{INTRODUCTION}

Turkey is considered one of the main sources of proteins. Turkey industry in

Corresponding author: Halla M. Kalill E-mail address:dremanismail201@gmail.com Present address: Biochemistry, Animal Health Research Institute (Zagazig Branch) Agriculture Research Center
Egypt was progressed in last few years and numerous farms had developed different breeds.

Mycoplasmosis is a contagious disease causing economic losses in poultry (ElAshram et al., 2021). $M G$ infection referred "chronic respiratory disease," in chickens and infect-ious sinusitis in turkeys as 
characterized by nasal discharge, tracheal rale, coughing, and dyspnea (Levisohn and Kleven, 2000). $M G$ infection causes economic losses by growth retardation, increased feed conversion rate, increased mortality rate (Kleven, 2008). Controlling $M G$ disease on a global level is done by eradication of positive breeder flocks or by vaccination and medication (Raviv and Hey, 2013).

Tiamulin are used to treatment $M G$ infection, respiratory and genital-urinary organs mucus are preferred (Bozorgmehri et al., 1998). Tiamulin binds at 50S ribosomal subunit with rRNA in which it prevents correct positioning of tRNA for peptide transferase and subsequent bacterial protein production (Poulsen et al., 2001).

Fluroquinolone compounds are wide spectrum bactericidal activity against mycopla-sma (Andon, 1993). Pefloxacin is one of a third generation of fluoroquinolones with broad spectrum activity against many bacterial diseases in poultry as salmonellosis, infectious coryza and avian mycoplasmosis (Mohamed and Dardeer, 2001).

The purpose of this study was to evaluate the efficacy of pefloxacin and tiamulin against $M G$ infected turkey poults together with a special reference to the immune response and some biochemical parameters.

\section{MATERIALS AND METHODS}

\section{Drug:}

1-Tiamulin (Tiamutin ${ }^{\circledR}$ ) water soluble granules contain $45 \mathrm{~g}$ tiamutin hydrogen fumerate. Produced by Sandoz Company, Austria.

2- Pefloxacin (Peflodad $10 \%{ }^{\circledR}$ ) solution was obtained from Dar Al Dawa Vet \& Agri Industrial Co. Itd. Jordan. Each ml contains $100 \mathrm{mg}$ of pefloxacin base.
Isolation and identification of Mycoplasma gallisepticum isolates:

Aseptic 40 swabs (lungs; trachea and air sacs) were tacken from 40 diseased poults suffe-ring from respiratory signs and subjected to bacteriological examination for isolation and identification mycoplasma spp. swabs were immersed into vials containing mycoplasma broth with bacterial inhibitors. Each swab was cultured into pleuropneumonia like organism broth and agar media with inhibitors and indicators for mycoplasma isolation (Adler et al., 1958). Isolates were biochemically identified (Frenske and Kenny 1976).

\section{Birds and experimental design:}

About 40, one day-old turkey poults were used in this trail at 14 days of age blood samples were tacken from them then subjected to serological examination by serum plate agglutination test to prove their free from Mycoplasma infection then poults were divided into four equal groups. $1^{\text {st }}$ group healthy poults (-ve control), $2^{\text {nd }}, 3^{\text {rd }}$ and $4^{\text {th }}$ groups were artificially infected with MG by inoculating in air sac with a pathogenic strain of $\mathrm{MG}$ at dose $0.2 \mathrm{ml}$ of $24 \mathrm{~h}$ broth culture of virulent strain of MG containing $2 \times 10^{8}(\mathrm{CFU}) / \mathrm{ml}$ (Moustafa, $2001), 2^{\text {nd }}$ group was infected, non-treated (+ve control), $3^{\text {rd }}$ group was infected treated with $5 \mathrm{mg}$ pefloxacin / $\mathrm{kg}$ bwt in drinking water for 5 days and $4^{\text {th }}$ groups was infected and treated with $25 \mathrm{mg}$ tiamulin/ $/ \mathrm{kg}$ bwt in drinking water for 5 days, Treatments was start after appear clinical signs (5 day post infection). Poults were individually weighed at $14^{\text {th }}$ day of age (Initial weight) and at $24^{\text {th }}$ day of age (Final weight) for estimation body weight gain and feed conversion rate.

\section{Sampling:}

At $1^{\text {st }}$ and $10^{\text {th }}$ days post treatment 5 poults from each group were sacrificed for record Lesion scores \% and two blood samples were taken from each group

$\mathbf{1}^{\text {st }}$ blood sample was taken in tube contain EDTA for estimation leukocytic count 
(Jain, 1986), phagocytic\%, index and killing \% (Wilkinson, 1977 \& Lucy and Larry 1982).

$2^{\text {nd }}$ sample was taken in tube for obtain clear serum for estimation $T$. protein (Doumas et al., 1981) albumin (Drupt, 1974) globulin was calculated as difference between total proteins and albumin, AST and ALT (Reitman and Frankel 1957), ALP (John, 1982), creatinine (Henry, 1979), uric acid (James and White, 1971). Serum immunoglobulins (IgA, IgG \& IgM) were performed using SANDWICH Elisa (Erhard et al., 1992)

\section{Re-isolation of Mycoplasma gallisepticum}

Post poults sacrificed Swabs from air-sac and nasal cavity were taken from all poults post treatment for re-isolation of $M G$ post treatment then immersed into vials containing mycoplasma broth medium with bacterial inhibitors for culturing.

\section{F. Serological examination:}

Blood samples were collected from wing veins of turkey poults just before infection and at $1^{\text {st }}$ day post treatment for rapid serum plate agglutination test for antibodies to Mycoplasma gallisepticum according to Kempf et al. (1998).

Statistical analysis: The obtained data was analyzed by using computerized SPSS program version 16 according to Tamhane and Dunlop (2000).

\section{RESULTS}

Turkey poults infected with MG showed clinical sign represented by loss of appetite, depression, sneezing, gasping, conjunctivitis, frothy exudation from eye, decrease body weight, increase in FCR and gross pathological lesions \{ air sacculitis 7 (70\%), pericard-itis $9(90 \%)$, perihepatitis $8(80 \%$ ) \} and mortality rate 4(40\%) (Table $2 \& 3$ ).

Mycoplasma gallisepticum induced significant increase in leukocytic count, serum AST, ALT, ALP, uric acid and cretonne beside significant decrease in phagocytic \%, index, killing \%, total protein, albumin, globulin coupled with insignificant decrease in $\operatorname{Ig} \mathrm{A}, \operatorname{IgG}$ and $\operatorname{Ig} \mathrm{M}$ ) allover expermental period post infection (Table 4 \& 6).

Medication infected poults using tiamulin or pefloxacin showed disappear of clinical signs, reduced mortality rate to $10 \%, \mathrm{Re}$ solution of MG from infected poult treated with pefloxacin or tiamulin were $(20 \%)$ and $(10 \%)$ respectively in comparison with $(100 \%)$ of infected non treated poults coupled with mild lesion scores, improve body weights and FCR post treatment (Table, 1, $2 \& 3$ ).

leukocytic count, phagocytosis \%, phagocytosis index, killing \%, serum total protein, albumin, globulin, $\operatorname{IgA}, \operatorname{IgG}$ and IgM, AST, ALT, ALP, uric acid, creatinine and returned to nearly normal levels at $10^{\text {th }}$ day post treatment (Table 4,5 \& 6).

Table 1: Incidence of the isolated mycoplasma from turkey poults.

\begin{tabular}{cccccc}
\hline \multirow{2}{*}{ Source of swabs } & \multirow{2}{*}{$\begin{array}{c}\text { Total No. } \\
\text { of swabs }\end{array}$} & No & \% & No & \% \\
\cline { 3 - 6 } & 15 & 8 & 53.33 & 7 & 48.66 \\
\hline Air sac & 15 & 6 & 40 & 9 & 60 \\
\hline Lungs & 10 & 4 & 40 & 6 & 60 \\
\hline Trachea & 40 & 18 & 45 & 22 & 55 \\
\hline Total & & & & &
\end{tabular}


Table 2: Effect of mycoplasma pefloxacin and tiamulin on mortality rate and bacteria reisolation of turkey poults.

\begin{tabular}{cccccc}
\hline \multirow{2}{*}{$\begin{array}{c}\text { Parameters } \\
\text { Groups }\end{array}$} & Total No & \multicolumn{2}{c}{ Mortality } & \multicolumn{2}{c}{ mycoplasma re-isolation } \\
\cline { 2 - 6 } & 10 & No & $\%$ & No & $\%$ \\
\hline GP 1 & 10 & 4 & 00 & 00 & 00 \\
\hline GP 2 & 10 & 1 & 10 & 6 & 100 \\
\hline GP 3 & 10 & 1 & 10 & 1 & 20 \\
\hline GP 4 & & & & & 10 \\
\hline
\end{tabular}

Table 2: Effect of mycoplasma, pefloxacin and tiamulin on pathological lesions, mortality rate and bacteria re-isolation of turkey poults.

\begin{tabular}{|c|c|c|c|c|c|c|c|c|}
\hline \multirow{2}{*}{$\begin{array}{c}\text { Parameters } \\
\text { Groups }\end{array}$} & \multicolumn{2}{|c|}{ GP 1} & \multicolumn{2}{|c|}{ GP 2} & \multicolumn{2}{|c|}{ GP 3} & \multicolumn{2}{|c|}{ GP 4} \\
\hline & No & $\%$ & No & $\%$ & No & $\%$ & No & $\%$ \\
\hline Total No & \multicolumn{2}{|c|}{10} & \multicolumn{2}{|c|}{10} & \multicolumn{2}{|c|}{10} & \multicolumn{2}{|c|}{10} \\
\hline A.sacculitis & 00 & 00 & 7 & 70 & 2 & 20 & 1 & 10 \\
\hline Pericarditis & 00 & 00 & 9 & 90 & 1 & 10 & 1 & 10 \\
\hline Perihepatitis & 00 & 00 & 8 & 80 & 2 & 20 & 1 & 10 \\
\hline
\end{tabular}

Table 3: Effect of pefloxacin and tiamulin on body weight of turkey poults $(n=5)$.

\begin{tabular}{lcccc}
\hline Parameters and Groups & GP 1 & GP 2 & GP 3 & GP 4 \\
\hline IBW $(\mathrm{gm})\left(14^{\text {th }}\right.$ day of age $)$ & $240.13 \pm 2.18 \mathrm{a}$ & $241.24 \pm 1.96 \mathrm{a}$ & $245.21 \pm 1.86 \mathrm{a}$ & $243.25 \pm 1.64 \mathrm{a}$ \\
\hline FBW $(\mathrm{gm})\left(24^{\text {th }}\right.$ day ofage $)$ & $558.98 \pm 4.32 \mathrm{a}$ & $515.34 \pm 2.76 \mathrm{~b}$ & $555.55 \pm 4.76 \mathrm{a}$ & $551.21 \pm 5.65 \mathrm{a}$ \\
\hline Weight gain $(\mathrm{gm})$ & $318.85 \pm 4.84 \mathrm{a}$ & $274.10 \pm 5.72 \mathrm{~b}$ & $310.34 \pm 3.49 \mathrm{a}$ & $307.96 \pm 3.64 \mathrm{a}$ \\
\hline Feed consumpion & 518.35 & 509.28 & 515.34 & 508.04 \\
\hline Feed conversion ratio & 1.63 & 1.86 & 1.66 & 1.65 \\
\hline
\end{tabular}

Means with different superscripts of the same raw indicate significant difference at $\mathrm{P}<0.05$

Table 4: Effect pefloxacin and tiamulin on WBCs, Phagocytosis\% and Killing\% of poults $(n=5)$.

\begin{tabular}{|c|c|c|c|c|c|}
\hline period & $\begin{array}{c}\text { Parameters and } \\
\text { Groups }\end{array}$ & GP 1 & GP 2 & GP 3 & GP 4 \\
\hline \multirow{4}{*}{$1^{s t} d a y$} & 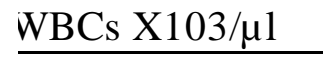 & $13,51 \pm 0,24 \mathrm{~b}$ & $15,83 \pm 0,58 \mathrm{a}$ & $14,94 \pm 0,35 \mathrm{a}$ & $14,89 \pm 0,49 \mathrm{a}$ \\
\hline & Thagocytosis & $54.89 \pm 1.21 \mathrm{a}$ & $49.21 \pm 1.23 \mathrm{~b}$ & $51.07 \pm 1.12 \mathrm{~b}$ & $51.12 \pm 1.06 \mathrm{~b}$ \\
\hline & Shagocytic index & $6.81 \pm 0.55 \mathrm{a}$ & $4.51 \pm 0.28 \mathrm{~b}$ & $4.89 \pm 0.33 \mathrm{~b}$ & $4.99 \pm 0.24 \mathrm{~b}$ \\
\hline & Killing\% & $68.41 \pm 0.96 \mathrm{a}$ & $63.03 \pm 0.89 b$ & $64.85 \pm 0.72 b$ & $65.16 \pm 0.55 b$ \\
\hline \multirow{4}{*}{$10^{\text {th }}$ day } & 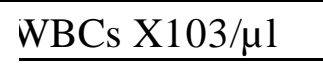 & $13,28 \pm 0,47 \mathrm{~b}$ & $15,58 \pm 0,57 \mathrm{a}$ & $14,23 \pm 0,41 \mathrm{a}$ & $14,11 \pm 0,69 \mathrm{a}$ \\
\hline & Thagocytosis & $54.96 \pm 1.42 \mathrm{a}$ & $49.13 \pm 1.13 b$ & $53.43 \pm 1.57 \mathrm{a}$ & $53.38 \pm 1.45 \mathrm{a}$ \\
\hline & Shagocytic index & $6.70 \pm 0.48 \mathrm{a}$ & $4.43 \pm 0.39 b$ & $5.57 \pm 0.58 \mathrm{a}$ & $5.63 \pm 0.43 \mathrm{a}$ \\
\hline & Killing\% & $68.73 \pm 0.89 a$ & $63.21 \pm 0.78 b$ & $66.79 \pm 0.84 a$ & $66.90 \pm 0.93 a$ \\
\hline
\end{tabular}

Means with different superscripts of the same raw indicate significant difference at $\mathrm{P}<0.05$ 
Table 5: Effect of pefloxacin and tiamulin on liver and kidney function of turkey poults $(n=5)$.

\begin{tabular}{|c|c|c|c|c|c|c|}
\hline period & \multicolumn{2}{|c|}{$\begin{array}{c}\text { Parameters and } \\
\text { Groups }\end{array}$} & GP 1 & GP 2 & GP 3 & GP 4 \\
\hline \multirow{5}{*}{$1^{s t} d a y$} & \multirow{3}{*}{$\begin{array}{l}\text { Liver } \\
\text { Enzymes } \\
(\mathrm{U} / \mathrm{L})\end{array}$} & $\mathrm{AST}$ & $79.43 \pm 1.0 \mathrm{c}$ & $85.34 \pm 1.16 \mathrm{a}$ & $84.19 \pm 1.21 \mathrm{~b}$ & $84.03 \pm 122 \mathrm{~b}$ \\
\hline & & ALT & $23.38 \pm 0.71 c$ & $27.04 \pm 0.68 \mathrm{a}$ & $25.13 \pm 0.27 \mathrm{~b}$ & $25.28 \pm 0.28 \mathrm{~b}$ \\
\hline & & ALP & $108.72 \pm 1.17 \mathrm{c}$ & $115.29 \pm 1.61 \mathrm{a}$ & $113.21 \pm 1.5 b$ & $113.28 \pm 1.49 \mathrm{~b}$ \\
\hline & \multirow{2}{*}{$\begin{array}{l}\text { Kidney } \\
\text { Function } \\
(\mathrm{gm} / \mathrm{dl}) \\
\end{array}$} & Uric acid & $4.14 \pm 0.20 \mathrm{c}$ & $5.41 \pm 0.18 \mathrm{a}$ & $4.82 \pm 0.14 \mathrm{~b}$ & $4.88 \pm 0.18 \mathrm{~b}$ \\
\hline & & Creatinine & $1.22 \pm 0.15 \mathrm{c}$ & $2.04 \pm 0.17 \mathrm{a}$ & $1.79 \pm 0.13 \mathrm{~b}$ & $1.77 \pm 0.11 \mathrm{~b}$ \\
\hline \multirow{5}{*}{$10^{\text {th }}$ day } & \multirow{3}{*}{$\begin{array}{l}\text { Liver } \\
\text { enzymes } \\
(\mathrm{U} / \mathrm{L})\end{array}$} & AST & $78.52 \pm 1.5 \mathrm{~b}$ & $85.13 \pm 1.30 \mathrm{a}$ & $80.13 \pm 1.52 \mathrm{~b}$ & $80.17 \pm 1.21 \mathrm{~b}$ \\
\hline & & ALT & $29.43 \pm 0.6 \mathrm{~b}$ & $31.3 \pm 0.19 \mathrm{a}$ & $30.21 \pm 0.37 \mathrm{~b}$ & $30.42 \pm 0.54 b$ \\
\hline & & ALP & $112.16 \pm 1.1 \mathrm{~b}$ & $117.06 \pm 1.23 \mathrm{a}$ & $113.78 \pm 1.9 \mathrm{~b}$ & $114.21 \pm 1.98 \mathrm{~b}$ \\
\hline & \multirow{2}{*}{$\begin{array}{l}\text { Kidney } \\
\text { Function } \\
(\mathrm{gm} / \mathrm{dl})\end{array}$} & Uric acid & $4.06 \pm 0.39 \mathrm{~b}$ & $5.43 \pm 0.20 \mathrm{a}$ & $4.21 \pm 0.34 \mathrm{~b}$ & $4.22 \pm 0.25 \mathrm{~b}$ \\
\hline & & Creatinine & $1.23 \pm 0.32 b$ & $2.15 \pm 0.12 a$ & $1.68 \pm 0.12 b$ & $1.70 \pm 0.14 b$ \\
\hline
\end{tabular}

Means with different superscripts of the same raw indicate significant difference at $\mathrm{P}<0.05$

Table 6: Effect of pefloxacin and tiamulin on humeral immunity of turkey poults $(n=5)$

\begin{tabular}{|c|c|c|c|c|c|c|}
\hline period & $\begin{array}{r}\text { Parame } \\
\text { Gro }\end{array}$ & $\begin{array}{l}\text { ers and } \\
\text { ups }\end{array}$ & GP 1 & GP 2 & GP 3 & GP 4 \\
\hline \multirow{7}{*}{$1^{s t} d a y$} & \multirow{4}{*}{$\begin{array}{l}\text { Protein } \\
\text { Picture } \\
(\mathrm{gm} / \mathrm{dl})\end{array}$} & T.protein & $5.50 \pm 0.28 \mathrm{a}$ & $4.60 \pm 0.15 \mathrm{~b}$ & $4.70 \pm 0.20 \mathrm{~b}$ & $4.75 \pm 0.19 \mathrm{~b}$ \\
\hline & & Albumin & $3.08 \pm 0.14 \mathrm{a}$ & $2.45 \pm 0.14 \mathrm{~b}$ & $2.40 \pm 0.23 \mathrm{~b}$ & $2.50 \pm 0.19 \mathrm{~b}$ \\
\hline & & Globuline & $2.42 \pm 0.10 \mathrm{a}$ & $2.05 \pm 0.11 \mathrm{~b}$ & $2.30 \pm 0.14 \mathrm{~b}$ & $2.25 \pm 0.10 \mathrm{~b}$ \\
\hline & & $\mathrm{A} / \mathrm{G}$ ratio & $1.27 \pm 0.11 \mathrm{a}$ & $1.20 \pm 0.14 \mathrm{a}$ & $1.04 \pm 0.10 \mathrm{a}$ & $1.11 \pm 0.15 \mathrm{a}$ \\
\hline & \multirow{3}{*}{$\begin{array}{l}\text { Immuno- } \\
\text { globulin } \\
(\mathrm{gm} / 100 \mathrm{ml})\end{array}$} & $\operatorname{IgA}$ & $3.82 \pm 0.41 \mathrm{a}$ & $2.89 \pm 0.53 \mathrm{a}$ & $3.21 \pm 0.81 \mathrm{a}$ & $3.64 \pm 0.47 \mathrm{a}$ \\
\hline & & IgM & $5.68 \pm 0.22 \mathrm{a}$ & $4.48 \pm 0.72 \mathrm{a}$ & $5.32 \pm 0.59 \mathrm{a}$ & $5.58 \pm 0.38 \mathrm{a}$ \\
\hline & & $\mathrm{IgG}$ & $9.58 \pm 0.37 \mathrm{a}$ & $8.32 \pm 0.69 \mathrm{a}$ & $9.17 \pm 0.48 \mathrm{a}$ & $9.38 \pm 0.70 \mathrm{a}$ \\
\hline \multirow{7}{*}{$10^{\text {th }}$ day } & \multirow{4}{*}{$\begin{array}{l}\text { Protein } \\
\text { Picture } \\
(\mathrm{gm} / \mathrm{dl})\end{array}$} & T.protein & $5.63 \pm 0.25 \mathrm{a}$ & $4.71 \pm 0.21 \mathrm{~b}$ & $5.70 \pm 0.22 \mathrm{a}$ & $5.73 \pm 0.19 \mathrm{a}$ \\
\hline & & Albumin & $3.03 \pm 0.14 \mathrm{a}$ & $2.60 \pm 0.12 b$ & $2.88 \pm 0.19 \mathrm{a}$ & $2.90 \pm 0.21 \mathrm{a}$ \\
\hline & & Globuline & $2.60 \pm 0.16 \mathrm{a}$ & $2.11 \pm 0.11 \mathrm{~b}$ & $2.82 \pm 0.21 \mathrm{a}$ & $2.83 \pm 0.19 \mathrm{a}$ \\
\hline & & $\mathrm{A} / \mathrm{G}$ ratio & $1.17 \pm 0.15 \mathrm{a}$ & $1.23 \pm 0.12 \mathrm{a}$ & $1.02 \pm 0.13 \mathrm{a}$ & $1.3 \pm 0.11 \mathrm{a}$ \\
\hline & \multirow{3}{*}{$\begin{array}{l}\text { Immuno- } \\
\text { globulin } \\
(\mathrm{gm} / 100 \mathrm{ml})\end{array}$} & $\operatorname{IgA}$ & $3.79 \pm 0.55 \mathrm{a}$ & $2.80 \pm 0.69 \mathrm{a}$ & $3.62 \pm 0.43 \mathrm{a}$ & $3.76 \pm 0.48 \mathrm{a}$ \\
\hline & & $\operatorname{IgM}$ & $5.89 \pm 0.48 \mathrm{a}$ & $4.59 \pm 0.58 \mathrm{a}$ & $5.77 \pm 0.39 \mathrm{a}$ & $5.82 \pm 0.61 \mathrm{a}$ \\
\hline & & $I g G$ & $9.47 \pm 0.60 a$ & $8.44 \pm 0.72 a$ & $9.28 \pm 0.38 a$ & $9.40 \pm 0.55 a$ \\
\hline
\end{tabular}

Means with different superscripts of the same raw indicate significant difference at $\mathrm{P}<0.05$

\section{DISCUSSION}

Poults infected with $M G$ showed clinical signs represented by depression, loss of appetite, sneezing, gasping, conjunctivitis with frothy exudation in the eyes and decreased body weight beside gross pathological lesions as air sacculitis $7(70 \%)$, pericarpditis $9(90 \%)$, perihepatitis $8(80 \%)$ and mortality rate $4(40 \%)$. Same clinical signs and mortality rate were observed by Saif et al. (2007) in broilers suffering from mycoplasmaosis. Same clinical signs were observed by Hany et al. (2019) in turkey suffering from mycoplasmosis and Andrea et al. (2020) in broilers infected with mycoplasma. Avian mycoplasmosis induced decrease in weight gain (Jay et al., 2021).

Infected poults treated with tiamulin or pefloxacin showed disappear of clinical signs, reduced mortality rate to $10 \%$ beside mild lesion scores, improve body weights 
and feed conversion rate. This improvement in body weights and feed conversion rate post treat-ment may be due to bactericidal effect of used drug on $M G$. Fluoroquinolones was effective in $M G$ in broilers (Kempf et al., 1998). Pefloxacin treated $M G$ revealed disappear clinical signs and reduced mortality rate (Mohamed and Mona 2002). treatment infected broilers by tiamulin reduced clinical signs, lesion scores and mortality (Zakeri and Kashefi 2011). Tiamulin effective against $M G$ in broilers (Farran et al., 2018).

Re-isolation rate of $\mathrm{MG}$ from poults treated with pefloxacin was $(20 \%)$ and $(10 \%)$ for tiamulin. Pefloxacin have bactericidal activity against MG infection and reduced re-isolation MG (El Sayed and Mahmoud 2003). Laying hens infected with mycoplasma treated with tiamulin reduced MG re-isolation (Masour et al., 2017).

In the present study, $M G$ infection induces leukocytosis beside Significant decrease in phagocytic $\%$, index and killing \%. Broilers infected with $M G$ showed leukocytosis, decrease in killing \% and phagocytosis (Avakian and Ley 1993). Mycoplasma infection revealed leucocytiosis and decrease phagocytosis (Malhat et al., 2005). $M G$ induce leukocytosis and decrease in phagocytosis and killing \% (Mohamed et al., 2007).

Medication $M G$ infected poult by tiamulin or pefloxacin revealed improved in WBCs, phagocytosis and killing \% and reterened to normal levels at $10^{\text {th }}$ day post treatment. Our results were agreed with those previously reported by Wieliczko et al. (1988) in broilers infected with $M G$ and treated by taimolin. Pefloxacin have good efficacy in treatment $M G$ and improve phagocytosis and killing \% (Mohamed and Mona 2002).

Our findings revealed, significant increase in AST, ALT, ALP, uric acid and cretonne allover experimental period post infection of poults with $M G$. These finding may be due to damage of hepatocyte by bacterial toxin (Coles, 1986). These results come in harmony with results reported by Abdalla and Adayel (2006) stated that $M G$ infection in broiler induce elevation in liver enzymes, uric acid and creatinine in chickens experimentally infected with $M G$ Infected poults treated with tiamulin or pefloxacin showed improved in liver enzymes, uric acid and cretonne. Same results were reported Mohamed and Mona (2002) stated that chickens infected with $M G$ treated with pefloxacin revealed improved in liver enzymes and kidney function (Mohamed and Mona (2002). Tiamulin effective against $M G$ in broilers and improved in AST, ALT, ALP, uric acid and cretonne (Bastamy et al., 2021).

In the present work, serum total protein, albumin and globulin significantly decreased in poults infected with $M G$. Reducton in total protein and albumin may be due to necrotic effect of Mycoplasma toxin on hepatocytes which are the main site of albumin synthesis (Sorkar et al., 2005). Mycoplasma gallisepticum induce significant reduction in total protein, albumin and globulin in broilers (Malhat $e t$ al., 2005 and Mohamed et al., 2007). Laying hens infected with mycoplasma gallisepticum showed decrease in serum total protein, albumin and globulin (Masour et al., 2017).

Infected poults treated by tiamulin or pefloxacin revealed improved in protein profile and reterened to normal levels at $10^{\text {th }}$ day post treatment. Tiamulin has good effect in treatment mycoplasma gallisepticum infected broilers and improved protein profile (Zakeri and Kashefi 2011). Also, Masour et al. (2017) stated that taimulin treatment infected broilers by mycoplasma gallisepticum showed improved protein picture.

Infected poults with $M G$ revealed insignificant decrease in $\operatorname{IgA}, \operatorname{IgG}$ and $\operatorname{IgM}$ allover experimental period post infection Mycoplasma infection induced reduction in 
immune-globulin (Romero et al., 2001). Same change in immunoglobulin was reported by Wijesurendra et al. (2017) in poults infected with $M G$.

Infected poults treated with tiamulin or pefloxacin showed improved in $\mathrm{IgA}, \mathrm{IgG}$, and $\operatorname{IgM}$ and retented to nearly normal levels at $10^{\text {th }}$ days post treatment. Improved in $\operatorname{IgA}, \operatorname{IgG}$ and $\operatorname{IgM}$ post treatment may be due to antibacterial effect of used drugs against $M G$ (Abd EI-Aziz 2002).

It could be concluded that pefloxacin and tiamulin was effective in treatment of $\mathrm{MG}$ in turkey and ameliorate severity of lesions besides improve adverse effect in biochemical and immunological parameters of the infected turkey poults.

\section{REFERENCES}

Abd El-Aziz, M. (2002): Handbook of Veterinary Pharmacology, $5^{\text {th }} \mathrm{Ed}$.

Adayel, S. and Abdalla, O. (2007): Efficacy of pefloxacin against salmon-ellosis in balady chicks. Zag. Vet. J., 35 (1): 71-78.

Adler, H.E.; Fabricant, J. and Berg, J. (1958): Symposium on chronic respiratory diseases of poultry. I. Isolation and identification of pleuropneumonia-like organisms of avian origin. Am. J. Vet. Res. 19 440-447.

Andon, A. (1993): Fluoroquinolone pharmacology. Bull Acad. Fran 65: 27-29

Andrea, M.; Michele, G.; Ilenia, R.; Miklós, $G$. and Salvatore, C. (2020): Molecular Differentiation of Mycoplasma gallisepticum Outbreak: A Last Decade Study on Italian Italian Farms Using GTS and MLST. Vaccines 8, 665-278

Avakian, A. and Ley, D. (1993): Protec tive immune response to Mycoplasma gallisepticum in respiratory-tract in infected chickens. Avian Dis. 37:697705
Bastamy, M.; Raheel, I.; Ellakany, H. and Orabi, A. (2021): Study of minimum inhibitory concentration against local field isolates of Mycoplasma gallisepticum from Egyptian broiler and layer chicken flocks. Inter. $\mathrm{J}$ of Vet. Sci. 10(10) 124-130.

Bozorgmehri, F.; Fotwati, A. and Shjadost, B. (1998): Diseases of Poultry, Training and Res. Unit of Agri As s of Kosar Economic p. 59-69.

Coles, E. (1986): Vet. Clinical Pathology. $4^{\text {thEd. }} \quad$ W.B. Saunders Comp., Philadelphia, Toronto, Mexico, Rio de Janeiro, Sydney, Tokyo, Hong Kong.

Doumas, B.; Carter, R.; Peers, T. and Schaffer, R. (1981): Method for determination-of total protein in serum. C lin. Chem. 27.1642

Drupt, F. (1974): determination of albumin. Phar. Bio. (9)

El-Ashram, S.; Abdel-Alim, G.; Abdelhamid, T. and Deif, H. (2021): prevalence of mycoplasmosis in broiler and layer in Giza, Egypt. Plos One 16(7) 60-71

El-Sayed, E. and Mahmoud, A. (2003): efficacy of doxycycline and/ or enrofloxacin in treatment of mycoplasma in broilers. Zag. Vet. j. 31 (2) 48- 57.

Erhard, M.; Vonquistrp, l.; Kasper, B. and Kiinlman, R. (1992): Develop-ment of specific enzyme linked immunosorbent antibody assay for detection immune-globulins G. M. A. by monoclonal antibodies. Poltry Sci 71:302-310.

Farran, M.; Shaib, $H$. and Majed, $H$. (2018): Evaluation of Antibiotics to Control Mycoplasma gallisepticum in Broilers. Poult Fish Wild Sci 6(1)9199

Frenske, J.D. and Kenny, G.E. (1976): Role of arginine deaminase in growth of Mycoplasma horminis. J. Bacteriol., 125: 501.

Hany, F.; Hatem, S. and Gado, R. (2019): Effect of mixed experimental infection with Mycoplasma 
gallisepticumin broiler chickens. Alex J of Vet. Sci. 61(1): 68-78

Henry, R.J. (1979): Determination of serum creatinine. Clinical Chemistry, rinciples and Techniques $2^{\text {nd }}$ Ed., Harper and Row P. 525.

Jain, N. (1986): Schalm Vet. Haematology

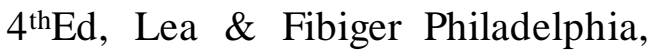
USA.

James, J. and White, W. (1971): Colorimetric estimation of serum uric acid. J. Clin. Chem., 17(3): 158-160.

Jay, P.; Piyush, T.; Yarvendra, S. and Sandip, K. (2021): Insights on Mycoplasma gallisepticum and Mycoplasma synoviae infection in poultry: a systematic review. j. of Animal Biotechnology40 (2) 321-332

John, D. (1982): laboratory mothed for determination of alkaline phosphatas $9^{\text {th }}$ Ed 580-581.

Kempf, I.; Cacou, P. and Bennejean, G. (1998): Evacuation de l' efficacite de la kitasamycine VP 2674 chez des Mycoplasma gallisepticum. Rec. Med. Vet., 164: 63-69.

Kleven, S. (2008): Control of avian mycoplasma infections in commercial poultry Avian Dis, 52 (1) 367-374.

Levisohn, S. and Kleven, S. (2000): Avian mycoplasmosis (Mycoplasma gallisepticum) rev Sci. Techn, 19 (2) 425-442.

Lucy, F. and Larry, D. (1982): Ontogeny and line diference as in mitogenic responses of chicken lymphocytes. Poultry Scien, 62: 79-94.

Malhat, S.; Ayoub, A. and Mankarios, E. (2005): Effect of kitasamycin on mycoplasma gallisepticum \& immune response in broilers. Zag. Vet. J33, 32-40.

Masour, E.; Hend, M.; Magda, N.; Mona, S. and Nahad, K. (2017): Efficacy of tiamulin in laying hens infected with mycoplasma. Ani. Heal Res. Inst. J. 5(4 A) 543-552.

Mohamed, M. and Mona, M. (2002): Efficacy of pefloxacin on mycoplasma infection in chickens. Vet. Med. J., (Giza), 50 (4): 733-739.
Mohamed, E. and Dardeer, M. (2001): Influence of combination of BCG vaccine and pefloxacin in chickens experimentally infected with Mycoplasma gallisepticum. J. Egypt. Vet. Med. Associ., 61 (2): 281-292.

Mohamed, A.; El-Nabtity, S. and Hussein, $S$. (2007): Effect of kitasamycin on mycoplasma gallisepticum infection in broiler biochemica nd pathologic al tudies. 5th Int. Sci. Conf., Mansoura 1352-1359

Moustafa, Zeinab, R. (2001): Evaluation of some mycoplasma vaccines in layer breeders. Ph D. Thesis, Fac. Vet. Med., Moshtohor. Banha University.

Poulsen, S.; Karlsson, M. and Vester, B. (2001): The pleuromutilin drug tiamulin and valnemulin bind to RNA at peptidyl transferase centre on ribosome. Mol. Micro. 41(1)51-57.

Raviv, Z. and Hay, D. (2013): Mycoplasma gallisepticum infection Disease. E. Swayn (Ed.), Diseases of poultry (13 $3^{\text {th }}$ edition.), Ames, Iowa pp. 877-89.

Reitman, S. and Frankel, S. (1957): Colorimetric determination of S.AST, S. ALT enzymatic activity. An. J. Clin. Path, 28: 56.

Romero, R.; Reyes, J. and Hadden, J. (2001): $\quad$ Immunomodulatory properties of Mycoplasma pulmonis. III. Lymphocyte stimulation and cytokine production by Mycoplasma pulmonis products. Int Immunophar. 1.99-107.

Sorkar, S.; Rahman, M.; Amin, K.; Rhan, M. and Rahman, M. (2005): Seroprevalence of Mycoplasma gallisepticum infection of chicken in model breeder poultry farms of Bangladesh. Int. J. Poult. Sci., 4 (1): 32-35.

Saif, Y.; Barnes, H.; Gilsson, J; Fadly, A.; Mc Dongald, L. and Swayne, D. (2007): Diseases of Poultry. $12^{\text {the }}$. Iowa state uni. Press (Blackwell Publishing Com), pp.31-56.

Tamhane and Dunlop (2000): Statics and data analysis from elementary to 
interme-diate. Upper Saddle River, USA.

Wieliczko, A.; Mazurkiewicz, M. and Pawiak, R. (1988): Efficacy of some antibiotics in controll mycoplasmosis in chicks. Meducuna. Vet. 2: 88-91

Wijesurendra, D.; Bacci, B. and Browning, $G$. (2017): Immune responses to vaccination and infection with
Mycoplasma gallisepticum in turkeys. Avian Pathol. 46(5): 464-473.

Wilkinson, $P$. (1977): Technique in clinic al immunology. Ed. By Thompson RA., Puplication .USA.P.201.

Zakeri, A. and Kashefi, P. (2011): efficacy of tiamulin in infected broiler and layer with Mycoplasma gallisepticum. Afr J Pharm Pharm 5: 178-181.

\section{دراسات فارماكولوجية على البيفلوكساسين والتيمولين فى بدارى تسمين الرومى هالة محد خليل ، نسرين احمد شوقى ، هالة على السعيد ، حماده العزازى}

E-mail: dremanismail201@gmail.com

Assiut University web-site: www.aun.edu.eg

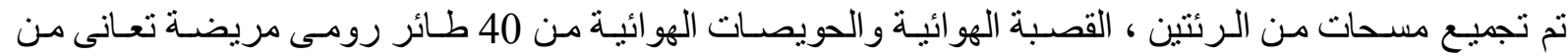

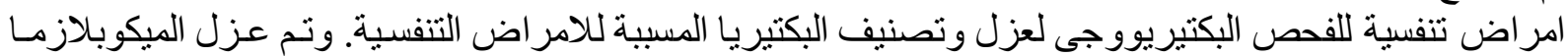

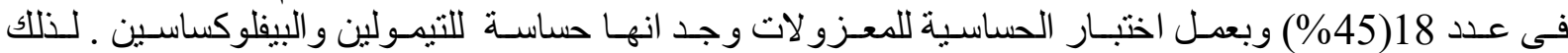

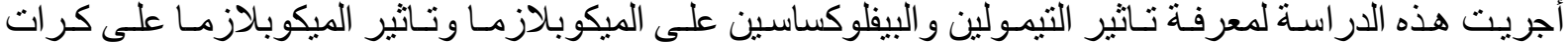

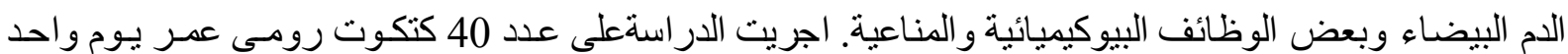

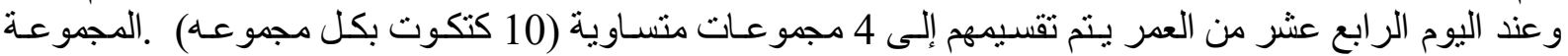

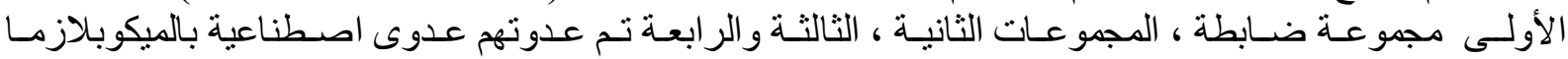

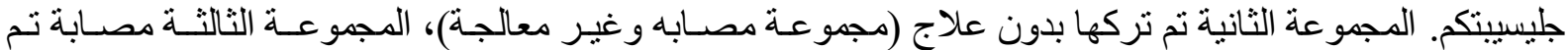

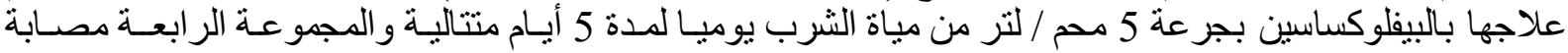

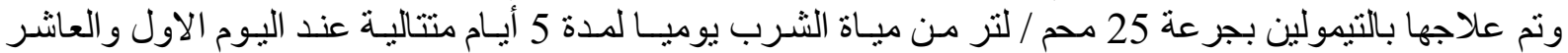

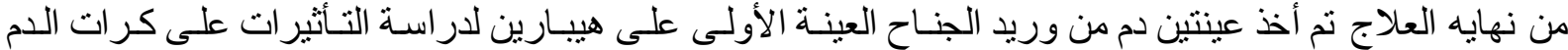

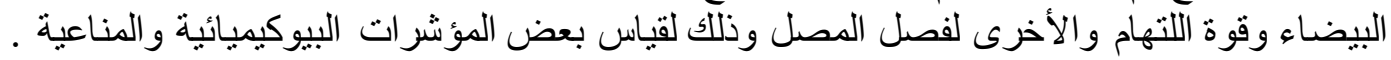

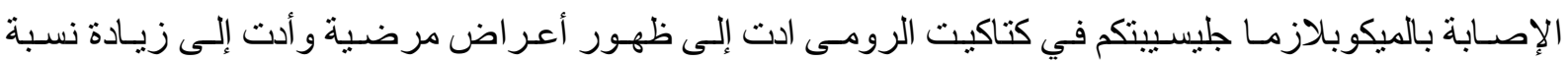

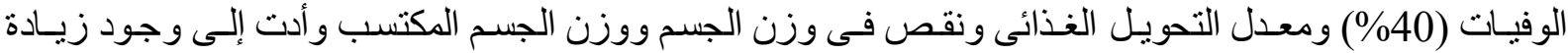

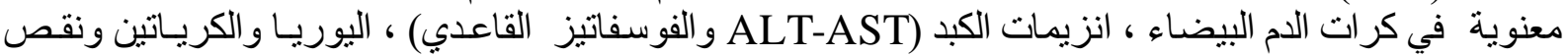

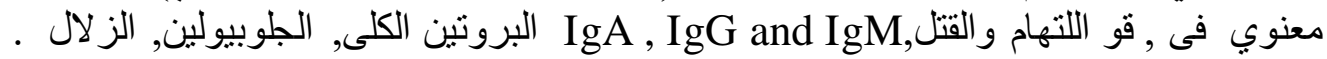

وقد أتضح من هذة الدرا سـة أن عقـارى البيفلوكساسين والتيمـولين أدى إلى اختفـاء الأعر اض وقلـل نسبة الوفيـات

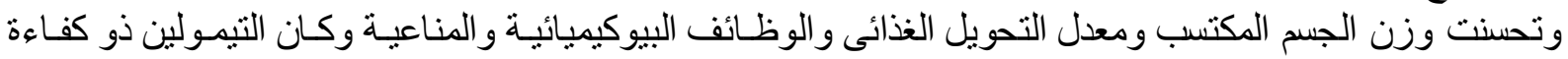
عالية عن البيفلوكساسين.

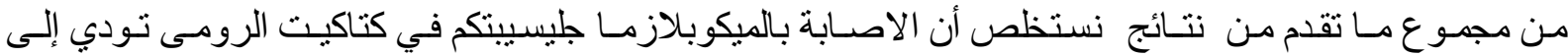

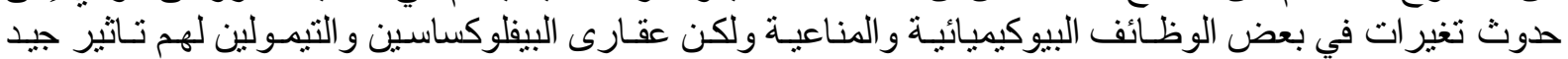

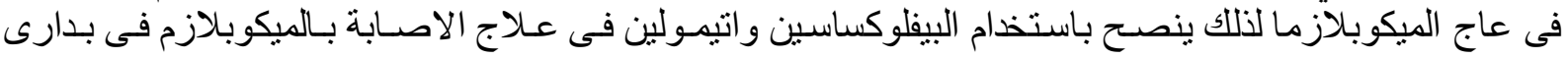
تسمين الرومى بكل امان. 